\title{
Purification, characterization and application of thermoalkaliphilic proteases from Bacillus filamentosus, Lysinibacillus cresolivorans, and Bacillus subtilis
}

Inam Ullah

Kohat University of Science and Technology

Nawab Ali

Kohat University of Science and Technology

Waheed Ullah ( $\sim$ waheedwazir@gmail.com )

Kohat University of Science and Technology https://orcid.org/0000-0002-2931-5386

Muhammed Qasim

Kohat University of Science and Technology

Muhammed Nughman

Kohat University of Science and Technology

Nimat Ullah

National University of Sciences and Technology

Muhammed Rashid

PMAS Arid Agriculture University: University of Arid Agriculture

Original article

Keywords: destaining, enzymes, phylogeny, thermophilic bacteria

Posted Date: January 28th, 2021

DOl: https://doi.org/10.21203/rs.3.rs-153220/v1

License: (a) (i) This work is licensed under a Creative Commons Attribution 4.0 International License.

Read Full License 


\section{Abstract}

Thermophilic proteases are important industrial enzymes because they can be used at unavoidable temperature in various bioprocessing schemes. The bacterial population of Cholistan desert was explored for thermophillic proteases and their industrial applications. Three bacterial isolates $\mathrm{K} 1, \mathrm{~K} 5$, and $\mathrm{K} 7$ were found promising protease producers. These isolates were preliminary identified as Bacillus based on morphological characteristics and biochemical tests (positive for catalase, oxidase, and citrate tests, and negative for indole and urease tests). The isolates $\mathrm{K} 1, \mathrm{~K} 5$, and $\mathrm{K} 7$ were further identified as Bacillus filamentosus, Lysinibacillus cresolivorans, and Bacillus subtilis, respectively by phylogenetic analysis. The isolates grew best at $50^{\circ} \mathrm{C}$ while Bacillus filamentosus (K1), Lysinibacillus cresolivorans (K5), and Bacillus subtilis $(\mathrm{K} 7)$ produced larger zones of hydrolysis at $37^{\circ} \mathrm{C}, 45^{\circ} \mathrm{C}$ and $50^{\circ} \mathrm{C}$ at $\mathrm{pH} 7$, respectively. The optimum temperature for protease activity was $65^{\circ} \mathrm{C}$ for Bacillus filamentosus and Lysinibacillus cresolivorans and $55^{\circ} \mathrm{C}$ for Bacillus subtilis, and the optimum $\mathrm{pH}$ for activity was 9 for all the three strains. The protease produced by these isolates were found active at high temperature $\left(37^{\circ} \mathrm{C}\right.$ to $\left.85^{\circ} \mathrm{C}\right)$ and high pH (5-12) which make them industrially important thermoalkaliphilic proteases. Theses proteases successfully de-haired cow's skin and de-stained blood from cotton cloth pieces, which are rarely tested applications of these proteases.

\section{Key Points}

- Deserts have microflora that inhabits diverse bacterial species of different attributes that are of great industrial importance

- These bacterial species have unique ability to tolerate high temperature and $\mathrm{pH}$

- The protease enzyme from these bacterial species can be used in leather and detergent industries as additives

\section{Introduction}

The global enzyme demand is increasing by $6.4 \%$ annually and proteases represents the largest commercially exploited enzyme, thus placed at the top of the list of industrially important enzymes (Dumorné 2017). Proteases demonstrate diverse physicochemical and biological functions and hence they are used in food, detergent, silk degumming, pharmaceutical, leather, film and waste processing industries. Therefore, protease accounts for more than $60 \%$ of the total enzyme sales worldwide (Singh 2016). In leather industry, protease is used to remove hairs from animal's skin and used for cleaning different kinds of stains like blood, grass and beetle in detergent industries. Around $70 \%$ of total proteases are used in leather and detergent industries (Mienda 2014). Nowadays, most of the industrial reactions take place at extreme conditions where normal enzymes denature, therefore, industries demand enzymes that can withstand harsh environmental conditions. Here, extremozymes are good alternatives because they can withstand harsh environmental conditions, are specific in action and environment friendly (Singh 2011). Thermophilic bacteria are considered a good source of thermostable enzymes (TE) 
which make them a suitable target for many industrial processes. These thermophilic bacterial strains reside in high temperature habitat like hot springs, deserts and deep-sea hydrothermal vents etc. (Mohammad 2017; Panosyan 2017). Proteases are very important and ubiquitous extracellular enzymes found in different sources i.e. plants, animals, and microbes. But, that of bacterial origin are preferred because of easy production, extraction, and purification with less cost and time (Niyonzima and More 2015). Thermophilic proteases (TP) produced by thermophilic bacterial strains have gained attention because the enzymes produced by thermophiles are active and stable at varied temperature and therefore are of great technological and industrial importance. Proteases isolated from these sources are not only active at higher temperature but sometimes they are also active at variable $\mathrm{pH}$ as well as in presence of organic salts (Akel 2009). A huge number of TE have been reported from bacterial origin that are being used in various biotechnological applications, among them, genus Bacillus have remained a good and dominant source (Kamran 2015; Mienda 2014). Bacterial enzymes are attractive for different reasons such as their enzymes are extracellular and regarded as safe for use. Some of the Bacillus species producing industrially important proteases are Bacillus subtilis and Bacillus licheniformis (Parrado 2014; Uttatree and Charoenpanich 2016).

Many microorganisms contain genes for protease enzyme but, we cannot use them for large industrial scale production. So, cloning is done in other microorganisms that can produce proteases in efficient way (Saggu and Mishra 2017). Many studies reported mesophilic proteases that are stable till $50^{\circ} \mathrm{C}$, however, less data is available about the thermostability of microbial proteases, that are important for industrial applications. Deserts usually have high temperature and the temperature usually changes with climate, hence inhabit diverse microbial community that have adapted to different environmental conditions (Cherif 2015). Since these microbes adapt environmental fluctuations and hence can result in isolation of robust enzymes that could be able to withstand extreme conditions. In a study, Bacillus cereus RS3 was isolated from desert in Riyadh, Saudi Arabia with thermophilic capabilities (Shine 2016). However, there is still need to search for polyextremophilic bacteria producing enough proteases that can stand active at different harsh conditions. Therefore, this study is designed to explore bacterial population of Cholistan desert, Pakistan for purification and characterization of TP and their industrial applications.

\section{Materials And Methods}

\section{Sample collection and bacterial isolation}

$50 \mathrm{~g}$ of soil samples $(n=10)$ were collected from the desert of Cholistan, Pakistan $\left(28.5^{\circ} \mathrm{N} 71.5^{\circ} \mathrm{E}\right)$ in sterile bottles and were stored until analysis at $4^{\circ} \mathrm{C}$. The samples were serially diluted and about $100 \mu \mathrm{l}$ mixture was poured onto nutrient agar (NA) plates and incubated at $50^{\circ} \mathrm{C}$ for 48 hours (Mohammad 2017). Morphologically different colonies were further purified by repeated streaking for several times.

\section{Screening for proteolytic activity}


Purified isolates $(\mathrm{n}=48)$ were dot inoculated on $1.5 \%(\mathrm{w} / \mathrm{v})$ skim milk agar $(\mathrm{SMA})$ plates and were incubated for 48 hours at $50^{\circ} \mathrm{C}$. The isolates that produced clear zone of hydrolysis $(\mathrm{CZH})$ around their colonies were recognized as protease producing (PP) isolates (Shine 2016). Among them, three efficient protease producing isolates (K1, K5 and K7) were selected for further studies such as identification, optimization of growth conditions, protease production and activity.

\section{Identification of bacterial isolates}

The selected isolates were preliminary identified by Gram staining and biochemical characteristics. Gram staining was performed as per the method described previously and biochemical tests were performed by API kit (20E CHB) as per manufacturer instructions (bioMerieux sa 62980, www.biomerieux.com). After preliminary identification, the isolates were further identified by $16 \mathrm{~s}$ rRNA gene based phylogenetic analysis. The genomic DNA (gDNA) was extracted as described previously with little modifications (Packeiser 2013). Briefly, bacterial colonies were picked from a fresh culture using a sterile tooth pack followed by inculcation in $200 \mu \mathrm{l} \mathrm{T.E} \mathrm{buffer} \mathrm{and} \mathrm{placed} \mathrm{at} 90^{\circ} \mathrm{C}$ for 10 minutes. The gDNA was obtained after centrifugation at 12000rpm for 5 minutes. The 16s rRNA gene was amplified in thermocycler using 16s rRNA gene primers, 9F (5'-GAGTTTGATCCTGGCTCAG-3') and 1510R (5'-GGCTACCTTGTTACGA-3'), using conditions described by (Ali 2016). The PCR products were sequenced and BLASTed in the server of the National Center for Biotechnology Information (NCBI) (http://blast.ncbi.nlm.nih.gov/Blast.cgi) to search for the related strains. A multiple alignment of the related strains was performed using MUSCLE and phylogenetic analysis was conducted by the neighbor-joining distance method to compute evolutionary distance in MEGA X software and the bootstrap values were calculated based on 1000 replications (Kumar 2018). The 16S rRNA sequences of K1, K5, and K7 were deposited in NCBI GenBank database (https://www.ncbi.nlm.nih.gov/genbank/) under accession numbers MN493608, MN493618, and MN493619, respectively.

\section{Bacterial Growth and protease production}

Growth of the isolates were optimized at different incubation temperature and $\mathrm{pH}$. For this, the isolates were grown in $10 \mathrm{ml}$ LB broth media and were incubated in shaking incubator at different temperatures $\left(37,45,50,55,60,65\right.$ and $\left.70^{\circ} \mathrm{C}\right)$ and $\mathrm{pH}(4,5,6,7,8,9,10$ and 11$)$ for 48 hours at $120 \mathrm{rpm}$. After 48 hours, the bacterial growth was measured by spectrophotometer at $600 \mathrm{~nm}$. The isolates were dot inoculated on SMA plates and incubated for protease production at different temperatures $(37,45,50,55$, 60 , and $\left.65^{\circ} \mathrm{C}\right)$ and $\mathrm{pH}(4,5,6,7,8,9$ and 10$)$ for 48 hours. $1.5 \%(\mathrm{w} / \mathrm{v})$ skim milk was used for temperature less than $55^{\circ} \mathrm{C}$, while for incubation at $55^{\circ} \mathrm{C}$ and above, $2 \%(\mathrm{w} / \mathrm{v})$ skim milk was used. After 48 hours of the incubation, the $\mathrm{CZH}$ were measured in millimeter $(\mathrm{mm})$ scale using measuring tape (Hamza 2018; Shaheen 2008).

\section{Optimization of protease activity of the isolates}

Protease activity was optimized using protease assay as described earlier (Ali 2016). Briefly, the isolates were grown in $\mathrm{LB}$ broth at $50^{\circ} \mathrm{C}$ and crude extract of extracellular enzymes was obtained. Then, $100 \mu \mathrm{l}$ solution of $0.5 \%$ casein prepared in $100 \mathrm{mM}$ phosphate buffer was added to $100 \mu \mathrm{l}$ crude enzyme and 
incubated at $37,45,50,55,60,65,70,75,80$ and $85^{\circ} \mathrm{C}$ at $\mathrm{pH} 5,6,7,8,9,10,11$, and 12 for $30 \mathrm{~min}$. The reaction was terminated by adding $100 \mu$ of $15 \%$ trichloro acetic acid (TCA) and the mixture was placed at room temperature. After $10 \mathrm{~min}$, the mixture was centrifuged at $13000 \mathrm{rpm}$ for $10 \mathrm{~min}$ and supernatant was transferred to another tube. Finally, $750 \mu \mathrm{l} 0.4 \mathrm{M} \mathrm{Na}_{2} \mathrm{CO}_{3}$ and $150 \mu \mathrm{l} \mathrm{Folin's} \mathrm{phenol} \mathrm{ciocalteus} \mathrm{reagent}$ ( 3 fold diluted) was added and incubated at $40^{\circ} \mathrm{C}$ for 20 min before measuring absorbance at $660 \mathrm{~nm}$.

\section{Protease applications of destaining and dehairing}

For the destaining and dehairing potential, protease enzyme was partially purified by Ammonium sulfate precipitation method followed by SDS-PAGE by method used by Ali (Ali 2016). A white cotton cloth piece $\left(4 \mathrm{~cm}^{2}\right)$ was stained with a drop of human blood, dried, and treated with formaldehyde. The dried cloth piece was placed in $30 \mathrm{ml}$ distilled water and treated with $10 \mathrm{ml}$ of proteases (extracted each from isolate $\mathrm{K} 1, \mathrm{~K} 5$, and K7) followed by incubation at $50^{\circ} \mathrm{C}$ in shaking incubator at $120 \mathrm{rpm}$ for $15 \mathrm{~min}$. Similarly, the cloth piece was treated with $10 \mathrm{mg} / \mathrm{ml}$ of local detergent (Bonus) and distilled water as positive and negative control, respectively. The results were observed, photographed, and compared (Rehman 2017). The dehairing process was carried out using a piece of cow's skin $\left(3 \mathrm{~cm}^{2}\right)$ and incubated in $50 \mathrm{ml}$ protease extract for 12 hours, while control was incubated in distilled water. After incubation, the skin was rubbed and flooded with water. The results were photographed for comparison (Rehman 2017). All the experiments were performed in triplicate and the data was analyzed in GraphPad Prism version 8.0.

\section{Results}

\section{Isolation and identification of protease producing bacteria}

A total of 48 bacterial isolates of different colony morphology were isolated from soil of Cholistan desert, Pakistan. Among them, 26 (54\%) bacterial isolates showed proteolytic activity. Among them, three isolates $\mathrm{K} 1, \mathrm{~K} 5$, and $\mathrm{K} 7$ produced larger zones $(19 \mathrm{~mm}, 24 \mathrm{~mm}$, and $26 \mathrm{~mm}$, respectively) of hydrolysis on SMA plates and were therefore selected for further studies as efficient protease producers (Fig. 1).

The selected isolates (K1, K5, and $\mathrm{K} 7)$ were gram-positive rods, and the API20E kit biochemical tests showed that all the three isolates were positive for ONPG, ADH, CIT, TDA, GEL, GLU, MAN, INO, RHA, SAL and MEL tests and negative for ODC, URE, $\mathrm{H}_{2} \mathrm{~S}$, IND, and AMY tests (Table 1). These preliminary results identified the isolates to be of Bacillus origin. After that, 16s rRNA gene sequence was BLAST at NCBI database, which revealed that the isolate $\mathrm{K} 1$ had $94.79 \%$ sequence identity and $94 \%$ query coverage with Bacillus filamentosus strain SGD-14, and $94.63 \%$ sequence identity and $97 \%$ query coverage with Bacillus endophyticus strain 2DT, the isolate K5 had $99.89 \%$ sequence identity and $97 \%$ query coverage with Lysinibacillus cresolivorans strain SC03, and $99.68 \%$ sequence identity and $98 \%$ query coverage with Lysinibacillus boronitolerans strain 10 a, while the isolate $\mathrm{K} 7$ had $99.89 \%$ sequence identity and $96 \%$ query coverage with Bacillus subtilis strain SBMP4, and $99.68 \%$ sequence identity and $99 \%$ query coverage with Bacillus velezensis strain FZB42 (Table 2). A neighbor joining phylogenetic tree revealed that the strain $\mathrm{K} 1$ belong to the genus Bacillus and share a distinct phyletic line with Bacillus 
filamentosus strain SGD-14 and Bacillus endophyticus strain 2DT (Fig. 2). Since, the strain K1 has higher sequence identity with the Bacillus filamentosus strain SGD-14 (Accession number NR_134701.1), therefore, the strain $\mathrm{K} 1$ was identified as Bacillus filamentosus. This was also supported by the phylogenetic tree obtained by the maximum-likelihood algorithms, where the isolate $\mathrm{K} 1$ form distinct phyletic line with Bacillus filamentosus strain SGD-14 (Figure S1). The neighbor joining phylogenetic tree further showed that the strain $\mathrm{K} 5$ is affiliated with genus Lysinibacillus and form distinct phyletic line with Lysinibacillus cresolivorans strain SC03 (Accession number NR_145635.1), and K7 strain is affiliated with genus Bacillus and form distinct phyletic line with Bacillus subtilis strain SBMP4 (Accession number NR_118383.1) (Fig. 2). This relationship was also found in the phylogenetic tree obtained by the maximum-likelihood and Neighborhood phylogenetic algorithms (Figure S1 and Figure S2).

Table 1. Biochemical characteristics of the selected isolates $\mathrm{K} 1, \mathrm{~K} 5$, and $\mathrm{K} 7$. 


\begin{tabular}{|c|c|c|c|}
\hline Biochemical tests & K1 & K5 & K7 \\
\hline ONPG & + & + & + \\
\hline ADH & + & + & + \\
\hline LDC & + & - & - \\
\hline ODC & - & - & - \\
\hline CIT & + & + & + \\
\hline $\mathrm{H}_{2} \mathrm{~S}$ & - & - & - \\
\hline URE & - & - & - \\
\hline TDA & + & + & + \\
\hline IND & - & - & - \\
\hline VP & - & - & + \\
\hline GEL & + & + & + \\
\hline GLU & + & + & + \\
\hline MAN & + & + & + \\
\hline INO & + & + & + \\
\hline SOR & + & + & - \\
\hline RHA & + & + & + \\
\hline SAC & + & + & - \\
\hline MEL & + & + & + \\
\hline AMY & - & - & - \\
\hline ARA & + & - & - \\
\hline
\end{tabular}

Table 2. 16s rRNA gene sequence NCBI BLAST results of K1, K5, and K7. 


\begin{tabular}{|lllll|}
\hline Isolate & Description & Identity & Query coverage & Accession number \\
\hline K1 & Bacillus filamentosus strain SGD-14 & $94.79 \%$ & $94 \%$ & NR_134701.1 \\
\cline { 2 - 5 } & Bacillus endophyticus strain 2DT & $94.63 \%$ & $97 \%$ & NR_025122.1 \\
\hline \multirow{2}{*}{ K5 } & Lysinibacillus cresolivorans strain SC03 & $99.89 \%$ & $97 \%$ & NR_145635.1 \\
\cline { 2 - 5 } & Lysinibacillus boronitolerans strain 10a & $99.68 \%$ & $98 \%$ & NR_041276.1 \\
\hline K7 & Bacillus subtilis strain SBMP4 & $99.89 \%$ & $96 \%$ & NR_118383.1 \\
\cline { 2 - 5 } & Bacillus velezensis strain FZB42 & $99.68 \%$ & $99 \%$ & NR_075005.2 \\
\hline
\end{tabular}

\section{Optimization of bacterial growth}

Growth of bacterial isolates (Bacillus filamentosus strain $\mathrm{K} 1$, Lysinibacillus cresolivorans strain $\mathrm{K} 5$, and Bacillus subtilis strain $\mathrm{K} 7$ ) were observed till $70^{\circ} \mathrm{C}$ and the optimum temperature for growth was recorded at $50^{\circ} \mathrm{C}$, which indicated the thermophilic nature of the isolates (Fig. $3 \mathrm{~A}$ ). The optimum pH for growth of three isolates were recorded as $\mathrm{pH} 7$, however, growth was also observed till $\mathrm{pH} 11$, which revealed the alkaliphilic nature of these bacteria (Fig. 3B). The diverse and extreme culturing conditions of these isolates may be possibly due to their diverse habitat (desert) where bacteria face harsh environmental conditions for their survival.

\section{Protease production and activity}

In this study, the optimum temperature of protease production was reported as $65^{\circ} \mathrm{C}$ which revealed the thermophilic nature of the isolates. However, the temperature for high protease production varied for each bacterium such as Bacillus filamentosus strain $\mathrm{K} 1$, Lysinibacillus cresolivorans strain $\mathrm{K} 5$, and Bacillus subtilis strain $\mathrm{K} 7$ produced maximum zones of hydrolysis at $37^{\circ} \mathrm{C}(28 \mathrm{~mm}), 45^{\circ} \mathrm{C}(25 \mathrm{~mm})$, and $50^{\circ} \mathrm{C}$ $(26 \mathrm{~mm})$, respectively (Fig. 4A). Similarly, the highest production of protease for all isolates were seen at pH 7 (Fig. 4B).

Different temperature and $\mathrm{pH}$ conditions affect the stability and activity of proteases therefore, temperature and $\mathrm{pH}$ were optimized for these isolates. The optimum activity of proteases produced by Bacillus filamentosus strain $\mathrm{K} 1$ was observed $170 \mathrm{U} / \mathrm{ml}$ at $65^{\circ} \mathrm{C}$ and Lysinibacillus cresolivorans strain $\mathrm{K} 5$ activity was $165 \mathrm{U} / \mathrm{ml}$ at $65^{\circ} \mathrm{C}$, however, maximum protease activity of $190 \mathrm{U} / \mathrm{ml}$ was observed at $55^{\circ} \mathrm{C}$ for Bacillus subtilis strain K7 (Fig. 5A). The proteases produced by these isolates were also active at high $\mathrm{pH}$ values (5 to 12). While, the maximum activity of the proteases produced by Bacillus filamentosus strain $\mathrm{K} 1(172.3 \mathrm{U} / \mathrm{ml})$, Lysinibacillus cresolivorans strain $\mathrm{K} 5(173 \mathrm{U} / \mathrm{ml})$, and Bacillus subtilis strain $\mathrm{K} 7$ (200.6 U/ml) was observed at pH 9 (Fig. 5B).

\section{Industrial applications of protease enzymes}


After the successful partial purification of protease enzyme, the destaining and dehairing potential have been investigated. The enzyme showed the potential to remove human blood stains from white cotton cloth (Fig. 6). The protease enzymes revealed significant destaining potential as shown in Fig. 6 and this suggested the importance of these proteases for industrial level applications after purification by chromatographic methods. The proteases isolated in this study were also checked for their dehairing potentials using cow's skin. These proteases revealed the dehairing potential as shown in Fig. 7. Enzyme from all the three isolates have successfully removed hairs from cow's skin. Fig 7A represents the cow skin only treated with distilled water while Fig 7B, 7C and 7D represents dehaired skin treated with the enzymes of Bacillus filamentosus, Lysinibacillus cresolivorans, and Bacillus subtilis respectively.

\section{Discussion}

Proteases are the chief marketing enzymes worldwide because they are extensively used in leather, detergent, textile, food and pharmaceutical industries (Sinha and Khare 2013). The initial identification of PP bacteria was observed by direct observation of clear zones produced by PP bacteria on SMA plates. This technique has also been used by many other researchers for initial screening of PP bacterial species based on CZH (Ali 2016; Asha and Palaniswamy 2018; Kamran 2015).

We have used API kit for the initial identification of the bacteria. This method is also used previously by several researchers to identify bacteria based on biochemical characteristics like the identification of Bacillus sp. isolated from marine water (Alnahdi 2012), tropical fruit flies (Thaochan 2010) and municipal waste water (Sonune and Garode 2018). The 16s rRNA gene sequencing method is used in this study for molecular identification of bacteria, which is more authentic method for microbial identification (Janda and Abbott 2007; Kai 2019). This technique has also been used for genetic studies and diversity of bacteria such as Streptococcus (Sasaki 2004). Bacillus spp. are the diverse group among all bacterial species and our results are in accordance with other researchers who identified bacteria using NCBI BLAST of 16S rRNA gene sequences (Lele and Deshmukh 2016; Mohammad 2017). In similar fashion, (Shine 2016), also identified Bacillus from desert soil of Riyadh, Saudi Arabia with potential of protease production using 16s rRNA sequencing (Shine 2016). In one of our previous article, Bacillus was reported as protease producer from salt mines of Karak, Pakistan (Ali 2016). It can be concluded that Bacillus is a diverse group of bacterial species that can produce protease enzymes and usually found abundantly in harsh environmental conditions.

All of our isolates showed best growth at $50^{\circ} \mathrm{C}$ and have tolerated temperature till $70^{\circ} \mathrm{C}$. A slightly higher optimum temperature for growth than our study was reported by a researcher who have isolated bacteria from hot springs (El-Gayar 2017). The higher temperatures could be due to the variable conditions of the extreme sampling sites. Growth optimization is necessary because microorganisms used in fermentation technology needs to be optimized at different parameters like $\mathrm{pH}$ and temperature, which is a prime step in fermentation technology. Therefore, we optimized the growth conditions both at different temperature and $\mathrm{pH}$ like one previously reported by (Aanniz 2015), who had isolated bacterial isolates from Moroccan 
hot springs, deserts and salt marshes and have observed and optimized bacterial growth at different high temperature and pH (Aanniz 2015).

Qualitative proteolytic optimization is the direct observation and measurement of clear zones on SMA plates (Omer and Humadi 2013; Saxena 2014). The results revealed that proteases produced by all the three isolates were active at a wide range of temperature $\left(37^{\circ} \mathrm{C}\right.$ to $\left.85^{\circ} \mathrm{C}\right)$ which make them industrially important thermostable proteases. According to literature, the optimum temperature for protease activity produced by a thermostable bacteria isolated from hot springs is $50^{\circ} \mathrm{C}$, however, proteases activity was also observed at higher temperature such as $90^{\circ} \mathrm{C}$ (El-Gayar 2017). In previous study, the alkaline PP Bacillus species have been reported from salt mines (Sehar and Hameed 2011), however, the thermoalkaliphilic proteases are least reported from desert soil especially from deserts located in Pakistan which can be used for bio-industrial applications at extreme operational conditions.

The enzymes from the isolates were tested for its potential to remove blood clots and the results obtained were promising. The potential of proteases as detergent additives is previously reported by few researchers (Bezawada 2011; Mendes 2009; SD and Tambekar 2013), however, the blood destaining potential of proteases is rarely reported. These thermoalkaliphilic proteases favors the stability and compatibility of these enzymes as detergent additives. The dehairing potential of thermoalkaliphilic proteases is under studied. Usually chemical detergents are used for dehairing processes in leather industry, which is not an ecofriendly process (Hakim 2018; Thanikaivelan 2004). In a report dehairing ability of proteases was reported for alkaline proteases (Hakim 2018). But in this study, we have isolated and investigated the dehairing potential of proteases which can stand active at high temperature and $\mathrm{pH}$. The destaining and dehairing potentials of these proteases can be exploited at extreme thermoalkaliphilic conditions for industrial applications including leather and textile industry.

The three bacterial isolates were selected from soil of Cholistan desert which revealed the bacterial growth and protease production at broad ranges of temperature $\left(37^{\circ} \mathrm{C}\right.$ to $\left.70^{\circ} \mathrm{C}\right)$ and $\mathrm{pH}(7$ to 11$)$. Although, the optimum pH was 9 for protease activity for all but optimum temperature was $65^{\circ} \mathrm{C}$ in case of Bacillus filamentosus strain $\mathrm{K} 1$, and Lysinibacillus cresolivorans strain $\mathrm{K} 5$, and $55^{\circ} \mathrm{C}$ for Bacillus subtilis strain $\mathrm{K} 7$. However, the proteases produced by these isolates have shown proteolytic activity at high temperature $\left(37^{\circ} \mathrm{C}\right.$ to $\left.85^{\circ} \mathrm{C}\right)$ and high $\mathrm{pH}(5-12)$ which make them industrially important thermoalkaliphilic proteases at extreme operational conditions. The proteases also successfully removed blood stain from cotton cloth and hairs from cow's skin, which revealed the importance of these enzymes as detergent and/or additive of detergent in leather and textile industry. This study also recommended that Cholistan desert represents an invaluable microbial flora which can be explored for production of other important enzymes and biomolecules of industrial importance.

\section{Declarations}

Authors' contributions. IU performed the experiments, conducted statistical analysis and wrote the draft manuscript and NA helped in experiments, designed the research project, statistical analysis and in 
writing the draft manuscript, and equally contributed as first author with IU. WU, MQ, MR and NU analyzed the data and provided suggestions to improve the manuscript.

Acknowledgements. The authors are grateful to the Higher Education Commission of Pakistan for financial support and the Department of Biotechnology and Genetic Engineering, Kohat University of Science and Technology for providing laboratory facilities to carry out research work.

Conflict of Interest: The authors declare that they have no conflict of interest.

Funding: This work was funded by Higher Education Commission of Pakistan (HEC)

Data availability: Not applicable

Ethics approval: The research work was approved by Kohat University of Science and Technology, Kohat (KUST) ethical committee.

Consent to participate: Not applicable

Consent for publication: The authors approved the manuscript and gave their consent for its submission to Applied Microbiology and Biotechnology.

Code availability: Not applicable

\section{References}

Aanniz T, Ouadghiri M, Melloul M, Swings J, Elfahime E, Ibijbijen J, Ismaili M, Amar M (2015)

Thermophilic bacteria in Moroccan hot springs, salt marshes and desert soils. Brazilian J Microbiol 46:443-453

Akel H, Al-Quadan F, Yousef TK (2009) Characterization of a purified thermostable protease from hyperthermophilic Bacillus strain HUTBS71. Eur J Sci Res 31:280-288

Ali N, Ullah N, Qasim M, Rahman H, Khan SN, Sadiq A, Adnan M (2016) Molecular characterization and growth optimization of halo-tolerant protease producing Bacillus subtilis Strain BLK-1.5 isolated from salt mines of Karak, Pakistan. Extremophiles 20:395-402

Alnahdi HS (2012) Isolation and screening of extracellular proteases produced by new Isolated Bacillus sp. J App Pharm Sci 2:71-74

Asha B, Palaniswamy M (2018) Optimization of alkaline protease production by Bacillus cereus FT 1 isolated from soil. J App Pharm Sci 8:119-127

Bezawada J, Yan S, John RP, Tyagi R, Surampalli R (2011) Recovery of Bacillus licheniformis alkaline protease from supernatant of fermented wastewater sludge using ultrafiltration and its characterization. Biotech Res Int 2011:1-11 
Cherif A, Tsiamis G, Compant S, Borin S (2015) BIODESERT: exploring and exploiting the microbial resource of hot and cold deserts. BioMed Res Int 2015 doi: 10.1155/2015/289457

Dumorné K, Córdova DC, Astorga-Eló M, Renganathan P (2017) Extremozymes: a potential source for industrial applications. J Microbiol Biotech 27:649-659

El-Gayar KE, Al Abboud MA, Essa AM (2017) Characterization of thermophilic bacteria isolated from two hot springs in Jazan, Saudi Arabia. J Pure App Microbiol 11:743-753

Hakim A, Bhuiyan FR, Iqbal A, Emon TH, Ahmed J, Azad AK (2018) Production and partial characterization of dehairing alkaline protease from Bacillus subtilis AKAL7 and Exiguobacterium indicum AKAL11 by using organic municipal solid wastes. Heliyon 4:e00646

Hamza TA (2018) Isolation and Characterization of Protease Producing Bacteria from Soil, in Arba Minch University, Abaya Campus. Am J Biologic Environ Stat 4:10-14

Janda JM, Abbott SL (2007) 16S rRNA gene sequencing for bacterial identification in the diagnostic laboratory: pluses, perils, and pitfalls. J Clin Microbiol 45:2761-2764

Kai S, Matsuo Y, Nakagawa S, Kryukov K, Matsukawa S, Tanaka H, Iwai T, Imanishi T, and Hirota K (2019) Rapid bacterial identification by direct PCR amplification of 16S rRNA genes using the MinION ${ }^{\mathrm{TM}}$ nanopore sequencer. FEBS Open Bio 9:548-557

Kamran A, Bibi Z, Kamal M (2015) Screening and enhanced production of protease from a thermophilic Bacillus species. Pak J Biochem Mol Biol 48:15-17

Kumar S, Stecher G, Li M, Knyaz C, Tamura K (2018) MEGA X: molecular evolutionary genetics analysis across computing platforms. Mol Bio Evol 35:1547-1549

Lele OH, Deshmukh PV (2016) Isolation and characterization of thermophilic Bacillus sp. with extracellular enzymatic activities from hot spring of Ganeshpuri, Maharashtra, India. Int J App Res Tech 2:427-430

Mendes C, Brito M, Porto T, Porto A, Bezerra R, Carvalho L, Caneiro-Leao A, Carneiro-da-Cunha M (2009) Aquaculture by-product: a source of proteolytic enzymes for detergent additives. Chemical Papers 63:662669

Mienda BS, Yahya A, Galadima I, Shamsir M (2014) An overview of microbial proteases for industrial applications. Res J Pharm Biol Chem Sci 5:388-396

Mohammad BT, Al Daghistani HI, Jaouani A, Abdel-Latif S, Kennes C (2017) Isolation and characterization of thermophilic bacteria from Jordanian hot springs: Bacillus licheniformis and Thermomonas hydrothermalis isolates as potential producers of thermostable enzymes. Int J Microbio 2017;1-12 
Niyonzima FN, More S (2015) Detergent-compatible proteases: microbial production, properties, and stain removal analysis. Prep Biochem Biotech 45:233-258

Omer SS, Humadi HG (2013) Qualitative and quantitative screening of alkaline protease production from some pathogenic bacteria. J Kerbala Uni 11:309-314

Packeiser H, Lim C, Balagurunathan B, Wu J, Zhao H (2013) An extremely simple and effective colony PCR procedure for bacteria, yeasts, and microalgae. App Biochem Biotech 169:695-700

Panosyan HH (2017) Thermophilic bacilli isolated from Armenian geothermal springs and their potential for production of hydrolytic enzymes. Int J Biotech Bioeng 3:239-244

Parrado J, Rodriguez-Morgado B, Tejada M, Hernandez T, Garcia C (2014) Proteomic analysis of enzyme production by Bacillus licheniformis using different feather wastes as the sole fermentation media. Enz Mic Tech 57:1-7

Rehman R, Ahmed M, Siddique A, Hasan F, Hameed A, Jamal A (2017) Catalytic role of thermostable metalloproteases from Bacillus subtilis KT004404 as dehairing and destaining agent. App Biochem Biotech 181:434-450

Saggu SK, Mishra PC (2017) Characterization of thermostable alkaline proteases from Bacillus infantis SKS1 isolated from garden soil. PloS one 12:e0188724

Sasaki E, Osawa R, Nishitani Y, Whiley RA (2004) ARDRA and RAPD analyses of human and animal isolates of Streptococcus gallolyticus. J Vet Med Sci 66:1467-1470

Saxena S, Verma J, Modi DR (2014) RAPD-PCR and 16S rDNA phylogenetic analysis of alkaline protease producing bacteria isolated from soil of India: Identification and detection of genetic variability. J Gen Eng Biotech 12:27-35

SD T, Tambekar D (2013) Compatibility and wash performance analysis of alkaline protease from bacillus pseudofirmus (JQ337958) with commercial detergents. Int J Pharm Chem Biolog Sci 3(3):738744.

Sehar S, Hameed A (2011) Extracellular alkaline protease by a newly isolated halophilic Bacillus sp. Glob J Biotech Biochem 6:142-148

Shaheen M, Shah AA, Hameed A, Hasan F (2008) Influence of culture conditions on production and activity of protease from Bacillus subtilis BS1. Pak J Bot 40:2161-2169

Shine K, Kanimozhi K, Panneerselvam A, Muthukumar C, Thajuddin N (2016) Production and optimization of alkaline protease by Bacillus cereus RS3 isolated from desert soil. Int J Adv Res Biol Sci 3:193-202 
Singh G, Bhalla A, Ralhan PK (2011) Extremophiles and extremozyrnes: Importance in current biotechnology. Extreme Life, Biospeol Astrobio 3(1):46-54

Singh R, Mittal A, Kumar M, Mehta PK (2016) Microbial proteases in commercial applications. J Pharm Chem Biol Sci 4:365-374

Sinha R, Khare SK (2013) Thermostable proteases. In: Thermophilic Microbes in Environmental and Industrial Biotechnology. Springer, pp 859-880

Sonune N, Garode A (2018) Isolation, characterization and identification of extracellular enzyme producer Bacillus licheniformis from municipal wastewater and evaluation of their biodegradability. Biotech Res Inn 2:37-44

Thanikaivelan P, Rao JR, Nair BU, Ramasami T (2004) Progress and recent trends in biotechnological methods for leather processing. TRENDS in Biotech 22:181-188 Thaochan N, Drew R, Hughes J, Vijaysegaran S, Chinajariyawong A (2010) Alimentary tract bacteria isolated and identified with API-20E and molecular cloning techniques from Australian tropical fruit flies, Bactrocera cacuminata and B. tryoni. J Insect Sci 10:131-138

Uttatree S, Charoenpanich $\mathrm{J}$ (2016) Isolation and characterization of a broad $\mathrm{pH}$-and temperature-active, solvent and surfactant stable protease from a new strain of Bacillus subtilis. Biocat Agri Biotech 8:32-38

\section{Figures}

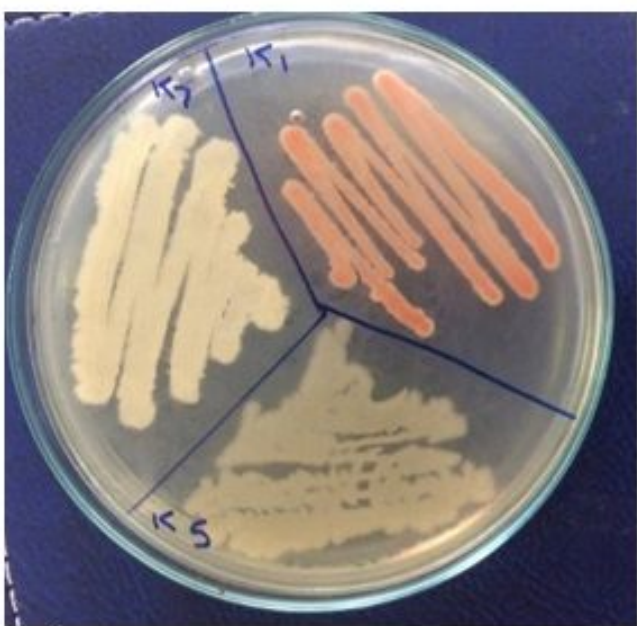

(A)

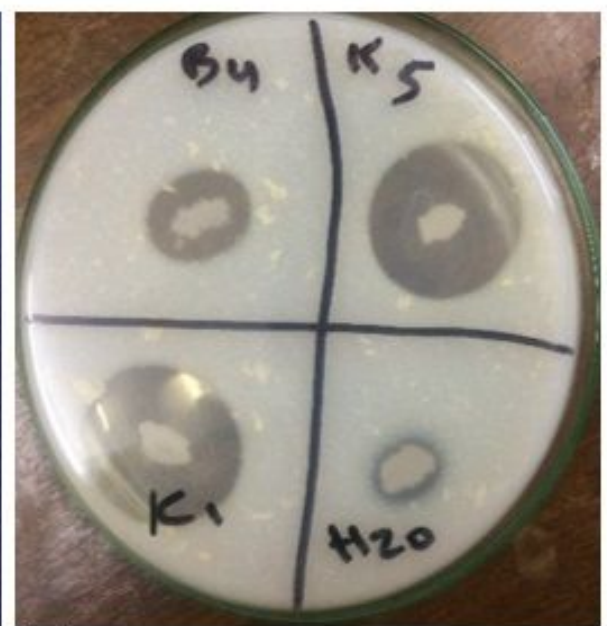

(B)

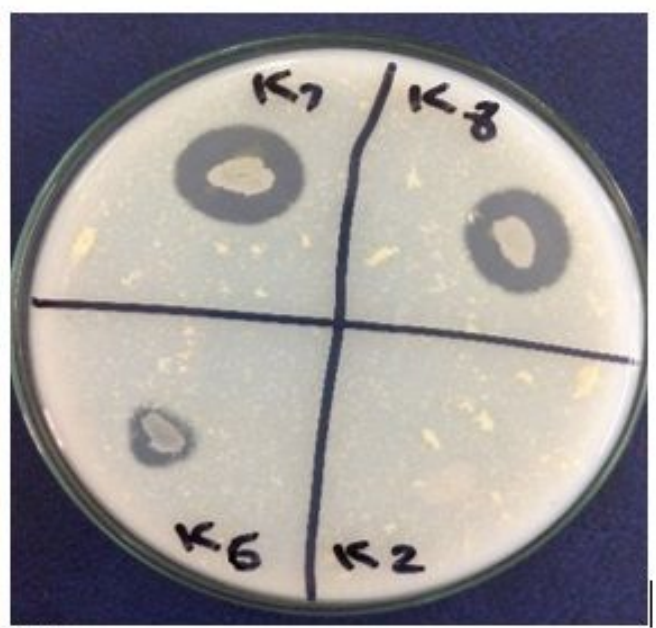

(C)

\section{Figure 1}

Growth of desert soil bacteria on nutrient and SMA plates. (A) Orange colonies of K1 and yellow colonies of $\mathrm{K} 5$ and $\mathrm{K} 7$ on NA plates, (B) CZH around $\mathrm{K} 1$, and $\mathrm{K} 5$, and (C) $\mathrm{K} 7$ colonies on SMA plates indicating proteolytic activity. 


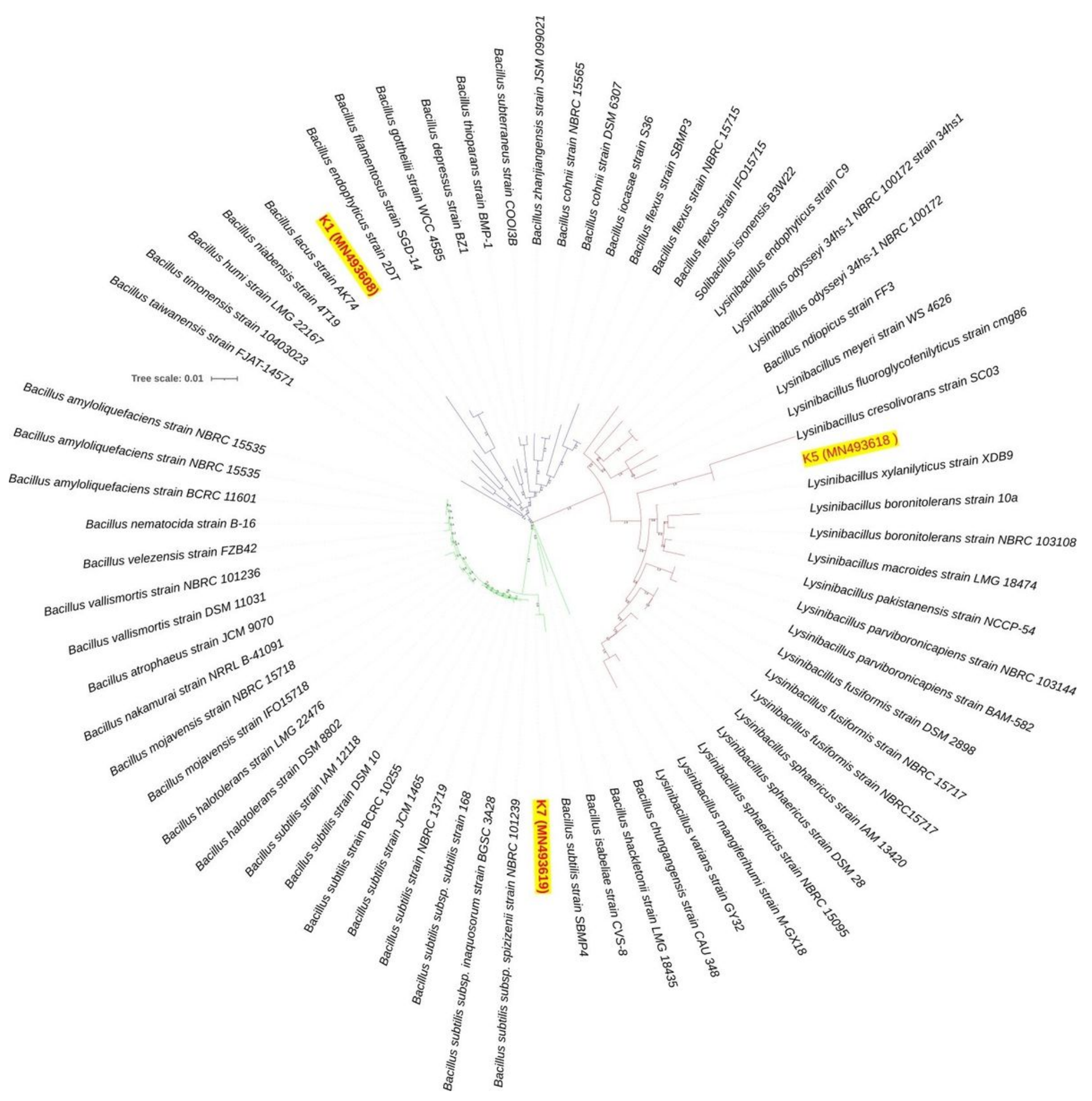

Figure 2

A neighbor joining phylogenetic tree based on variation in 16s rRNA gene sequence. The clades containing the isolates $\mathrm{K} 1, \mathrm{~K} 5$, and $\mathrm{K} 7$ (red and boldfaced with yellow background) are highlighted in blue, red, and green, respectively. Bootstrap values are shown in Supplementary File 2 and the tree was annotated using iTOL (https://itol.embl.de/). 

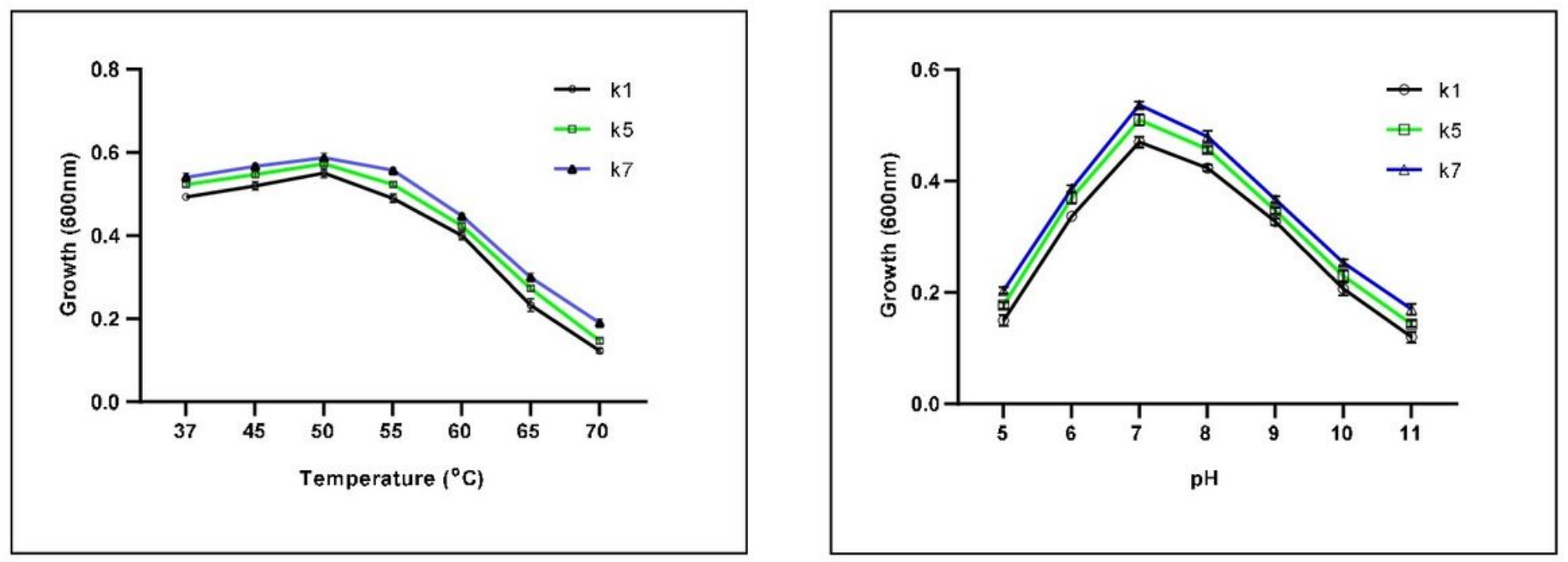

Figure 3

Growth of Bacillus filamentosus strain K1, Lysinibacillus cresolivorans strain $\mathrm{K} 5$, and Bacillus subtilis strain $\mathrm{K} 7$ at different $(\mathrm{A})$ temperature and $(\mathrm{B}) \mathrm{pH}$.
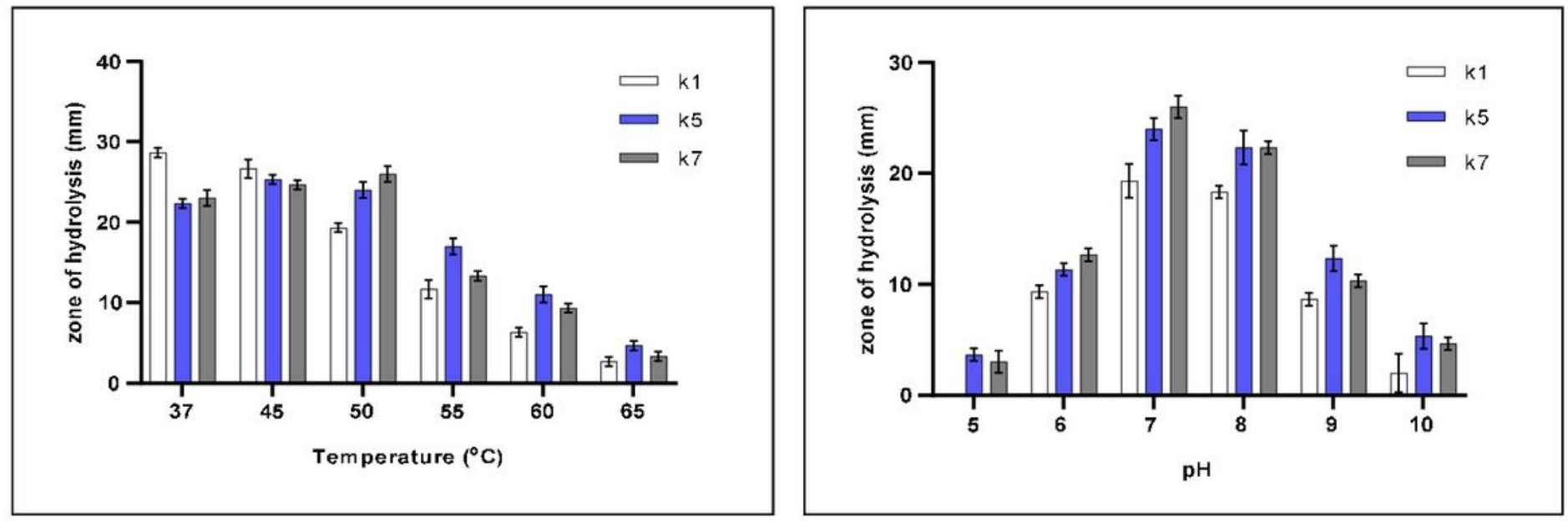

Figure 4

Protease production from Bacillus filamentosus strain $\mathrm{K} 1$, Lysinibacillus cresolivorans strain $\mathrm{K} 5$, and Bacillus subtilis strain $\mathrm{K} 7$ at different $(\mathrm{A})$ temperature and $(\mathrm{B}) \mathrm{pH}$. 

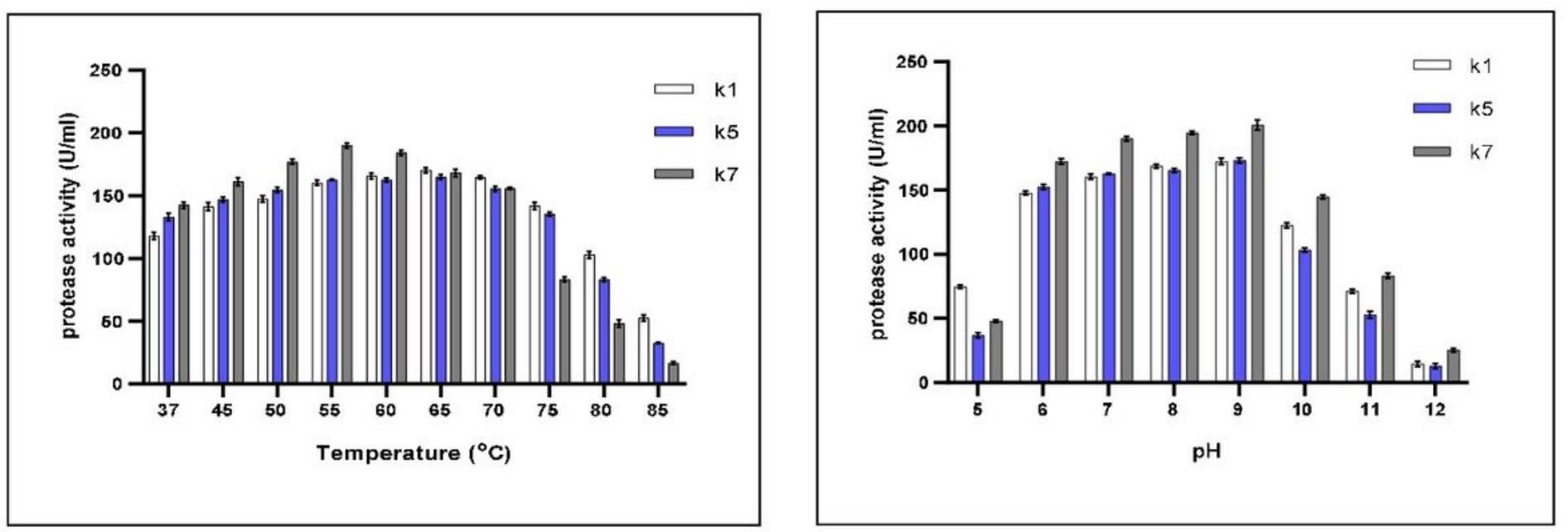

Figure 5

Protease activity optimization produced by Bacillus filamentosus strain K1, Lysinibacillus cresolivorans strain $\mathrm{K} 5$, and Bacillus subtilis strain $\mathrm{K} 7$ at different $(\mathrm{A})$ temperature and $(\mathrm{B}) \mathrm{pH}$.
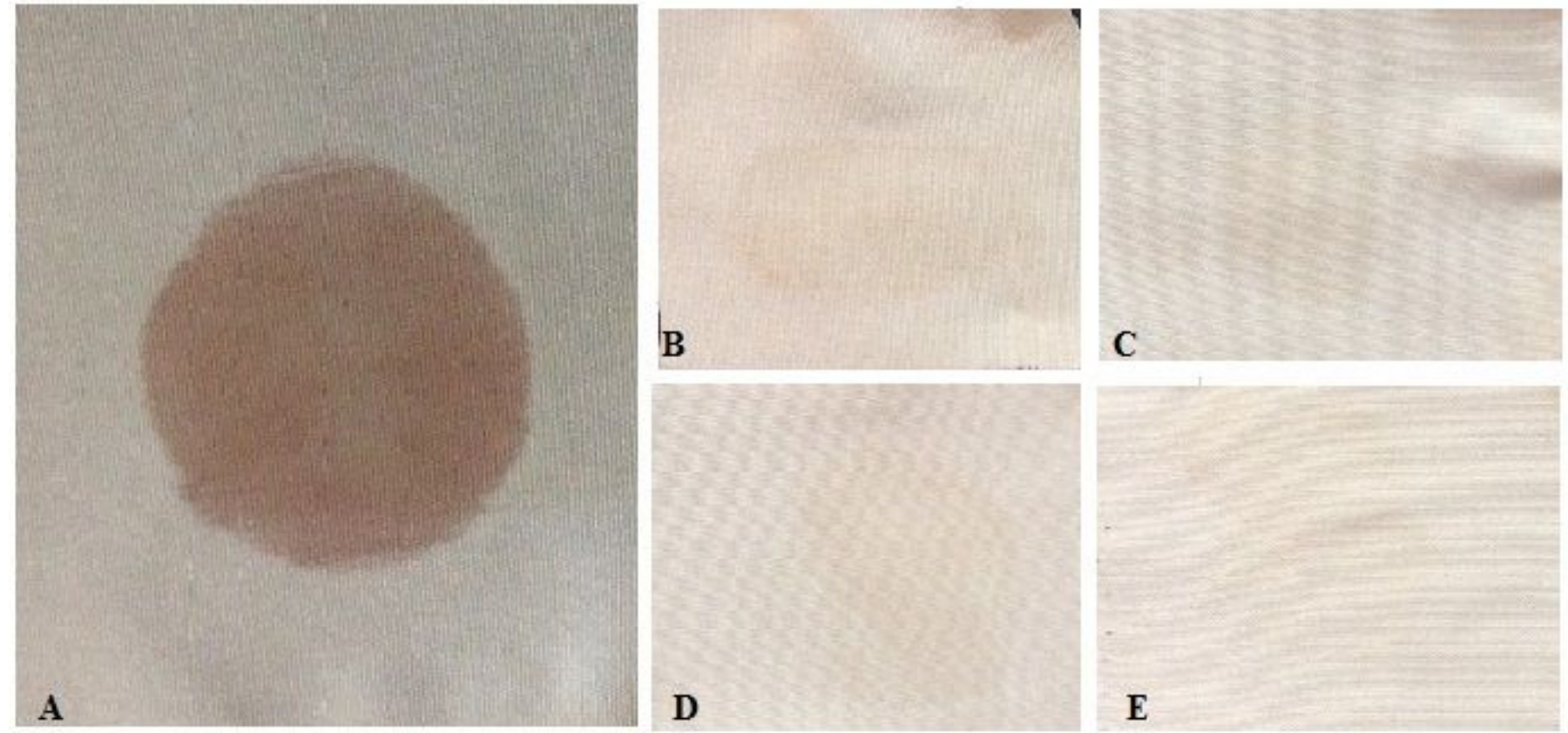

Figure 6

Blood de-staining with crude protease and local detergent. (A) Treated with distilled water, (B) crude protease from Bacillus filamentosus strain K1, (C) Lysinibacillus cresolivorans strain K5, (D) Bacillus subtilis strain $\mathrm{K} 7$, and $(\mathrm{E})$ with local detergent. 


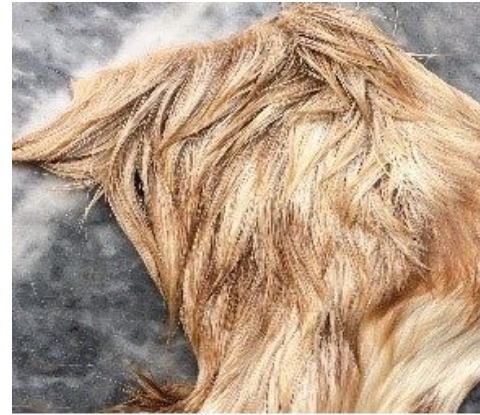

A

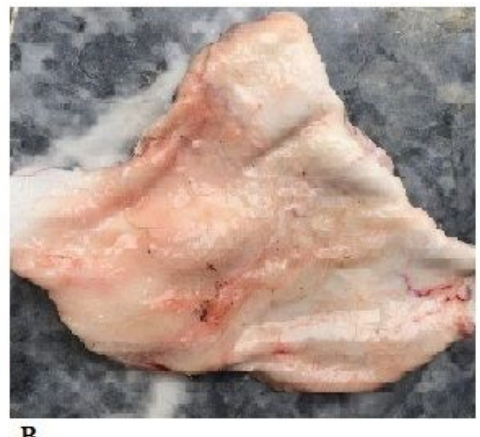

B
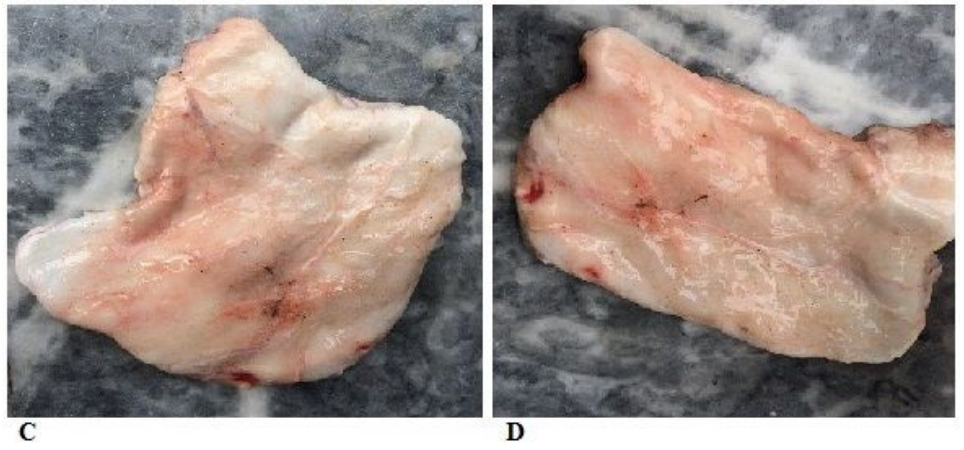

Figure 7

Dehairing of cow's skin with distilled water and crude proteases. (A) Treated with distilled water, (B) crude protease from Bacillus filamentosus strain K1, (C) Lysinibacillus cresolivorans strain K5, (D) Bacillus subtilis strain $\mathrm{K} 7$.

\section{Supplementary Files}

This is a list of supplementary files associated with this preprint. Click to download.

- SupplementaryFileRe.pdf 